\title{
Farmer Awareness to the Dangers of Heavy Metal Cadmium (Cd) Pollution due to Over-Fertilization in Sragen Regency Central Java
}

\author{
Visnu Pradika', Mohammad Masykuri ${ }^{2}$ and Supriyadi ${ }^{3 *}$ \\ ${ }^{1}$ Magister Student of Environmental Science, Universitas Sebelas Maret, Surakarta, Indonesia; ${ }^{2}$ Department of \\ Environmental Science, Postgraduate, Universitas Sebelas Maret, Surakarta, Indonesia; ${ }^{3}$ Department of Soil \\ Science, Faculty of Agriculture, Universitas Sebelas Maret, Surakarta, Indonesia \\ *Corresponding author: supriyadi_uns@staff.uns.ac.id
}

\begin{abstract}
$\mathrm{P}$ fertilization can add $\mathrm{Cd}$ metal content to agricultural land because the raw material for making $\mathrm{P}$ fertilizer comes from phosphate rock which naturally contains $\mathrm{Cd}$ metal. Farmers assume that by providing fertilizers with high doses can provide maximum results. Community's knowledge of heavy metals in the environment is still low. This study aims to examine the awareness of farmers in Sragen Regency Central Java to the potential of heavy metal pollution that occurs. This research was conducted from July to December 2017. The type of this research is quantitative descriptive research using a questionnaire with the number of respondents amounting to $10 \%$ of the number of farmers, namely 30 farmers. The results show that about $61.11 \%$ of the community doesn't understand that the presence of heavy metals in the environment can cause many problems. About $60 \%$ of the community doesn't understand that the inorganic fertilizers commonly used by them contain heavy metals (especially $\mathrm{Cd}$ metal). People unaware of heavy metal pollution due to over-fertilization is $65.01 \%$. Although the community's knowledge and awareness of heavy metals are still low, the community awareness about environmentally friendly agriculture is high $(61.33 \%)$. About $53.34 \%$ of the community doesn't know that their behavior in using inorganic fertilizers in the long term will increase the accumulation of $\mathrm{Cd}$ metal in agricultural land and rice plant tissue. About $70 \%$ of the community doesn't know that agricultural land that is used continuously to plant (without interspersed with non-paddy crops) will cause land degradation.
\end{abstract}

Keywords: Cadmium (Cd), farmer awareness, P fertilizer

Cite this as: Pradika, V., Masykuri, M., \& Supriyadi. (2019). Farmer Awareness to the Dangers of Heavy Metal Cadmium (Cd) Pollution due to Over-Fertilization in Sragen Regency Central Java. Caraka Tani: Journal of Sustainable Agriculture, 34(1), 76-85. doi: http://dx.doi.org/10.20961/carakatani.v34i1.27222

\section{INTRODUCTION}

Cadmium $(\mathrm{Cd})$ is a metal that has the potential to be toxic, very dangerous for the environment and for humans because of its long lifespan (Roberts, 2014). Toxicity of Cadmium as an industrial pollutant and food contaminants can cause multiple injuries in many organs, such as gills (branchia), kidneys, testicles, heart, liver, brain, bones and blood system (Sunarto, 2012). Cadmium metal is classified as non-essential metal whose presence is not needed in the body and tends to be toxic. The presence of cadmium metal which is toxic in the environment certainly will have a negative impact on living things around it (Fauzi et al., 2015; Zhu et al., 2017).

$\mathrm{Cd}$ contamination into agricultural land comes from three sources, namely from the air (pollution), irrigation and Phosphate fertilizer (Chen et al., 2007; Roberts, 2014; CruzParedes et al., 2017; Salmanzadeh et al., 2017).

\footnotetext{
${ }^{*}$ Received for publication January 23, 2019 Accepted after corrections March 26, 2019
} 
$\mathrm{P}$ fertilization can add $\mathrm{Cd}$ metal content to agricultural land because the raw material for making $\mathrm{P}$ fertilizer comes from phosphate rock which naturally contains Cd metal (Roberts, 2014; Bigalke et al., 2016). Cadmium (Cd) and Uranium (U) are the main contaminants in $\mathrm{P}$ mineral fertilizers and there are special concerns about this metal accumulating in the soil because it is toxic. The heavy metal content in $\mathrm{P}$ mineral fertilizer is varied greatly depending on the origin of the phosphate rock used and the nature of the finished fertilizer (Bigalke et al., 2017).

Cadmium occurs from natural processes in phosphate rock. The rocks which contain high phosphate also have higher cadmium content compared to the rocks that don't contain phosphate nutrients (Roberts, 2014). Most of the $\mathrm{Cd}$ metal moves from the soil to crop through harvesting and washing $\mathrm{Cd}$ to deeper soil layers (Ji et al., 2012; Bigalke et al., 2016). Irrigation can increase the mobilization of $\mathrm{Cd}$ metal, especially $\mathrm{Cd}$ metal which is adsorbed on the ground (Salmanzadeh et al., 2017).

$\mathrm{Cd}$ metal is toxic if accumulated in the human body can interfere the human health. Accumulated $\mathrm{Cd}$ metal can cause systemic health problems such as disorders of the kidneys, lungs, cardiovascular system and musculoskeletal system. Accumulation of $\mathrm{Cd}$ metal in plants can give an impact on the food chain system (Roberts, 2014; Qiutong and Mingkui, 2017).

Excessive of $\mathrm{Cd}$ metal concentrations in plants show symptoms such as dwarf growth, chlorosis, necrosis, browning of roots and even death $(\mathrm{He}$ et al., 2017). Excess Cd metal accumulation in plants can interfere with a series of physiological processes such as photosynthesis, respiration, nutrient uptake and water (Feng et al., 2010; Chang et al., 2013). The total Cd metal entering in Indonesian agricultural land is $12,675.3 \mathrm{~kg} \cdot \mathrm{yr}^{-1}$ with an estimated concentration of $0.0022 \mathrm{mg}$. $\mathrm{kg}^{-1}$ (FAO, 2007 cit. Seshadri et al., 2015).

Pollution of heavy metals in Indonesian agricultural land, especially in Java is influenced by the conditions of the people who grow rice throughout the year. Farmers fertilize using inorganic fertilizers that leaving more residue, one of which is heavy metal. Cultivation should provide a pause to plant other crops in one year, for example rice-secondary crops-rice (Hindarwati et al., 2018; Supriyadi et al., 2019)

The current problem is the assumption of farmers that by providing fertilizers with high doses can provide maximum results. Overfertilization using inorganic fertilizers can cause environmental damage and accumulation of heavy metals (Nungkat et al., 2015; Seshadri et al., 2015). Farmers use N, P and $\mathrm{K}$ inorganic fertilizers in their farming activities. The use of $\mathrm{P}$ fertilizer can add $\mathrm{Cd}$ metal content to agricultural land because the raw material for making $\mathrm{P}$ fertilizer comes from phosphate rock which naturally contains $\mathrm{Cd}$ metal (Roberts, 2014; Bigalke et al., 2017). So that there needs to be awareness and understanding of farmers in the danger of heavy metal pollution due to overfertilization. Based on the laboratory test before the research was conducted the $\mathrm{Cd}$ metal content in agricultural land on research location was 0.28 ppm, that content was exceeded the threshold value according to Government Regulation of Indonesia number 101 the year of 2014 that is 0.15 $\mathrm{ppm}$. Cd metal pollution is very dangerous for the environment and farmers. Metal Cd is difficult to ignore in agricultural activities and there is no information about the dangers of $\mathrm{Cd}$ metal, therefore studies of farmer awareness will be important to do.

This study aims to examine the awareness of farmers in Sambungmacan District, Sragen to the potential of heavy metal pollution that occurs. The results of the study are expected can be a recommendation for the parties concerned to provide the next steps to improving environmental quality.

\section{MATERIALS AND METHOD}

This research was conducted from July to December 2017. Administratively, the research location was in Bedoro village, Sambungmacan District, Sragen, Central Java, Indonesia. This location needs to be studied because local farmers always plant rice. Based on the laboratory test before the research was conducted, the $\mathrm{Cd}$ metal content in agricultural land on research location was $0.28 \mathrm{ppm}$, that content was exceeded the threshold value according to Government Regulation of Indonesia number 101 the year of 2014 that is $0.15 \mathrm{ppm}$.

The type of research is a quantitative descriptive by analyzing community responses about the potential of heavy metal pollution that occurs by using a validated questionnaire. The questionnaire was validated by two experts (panelist) because the formula used was content 
validity. The data was analyzed using statistic inferential. The type of questionnaire used in this study was a closed questionnaire because the respondents only had to give a sign on one of the answers that were considered correct. This research is descriptive, so the minimum sample is $10 \%$ of the population (Gay and Diehl, 1992). The number of farmers at the farm location is 293 people, so the number of respondents is 30 people.

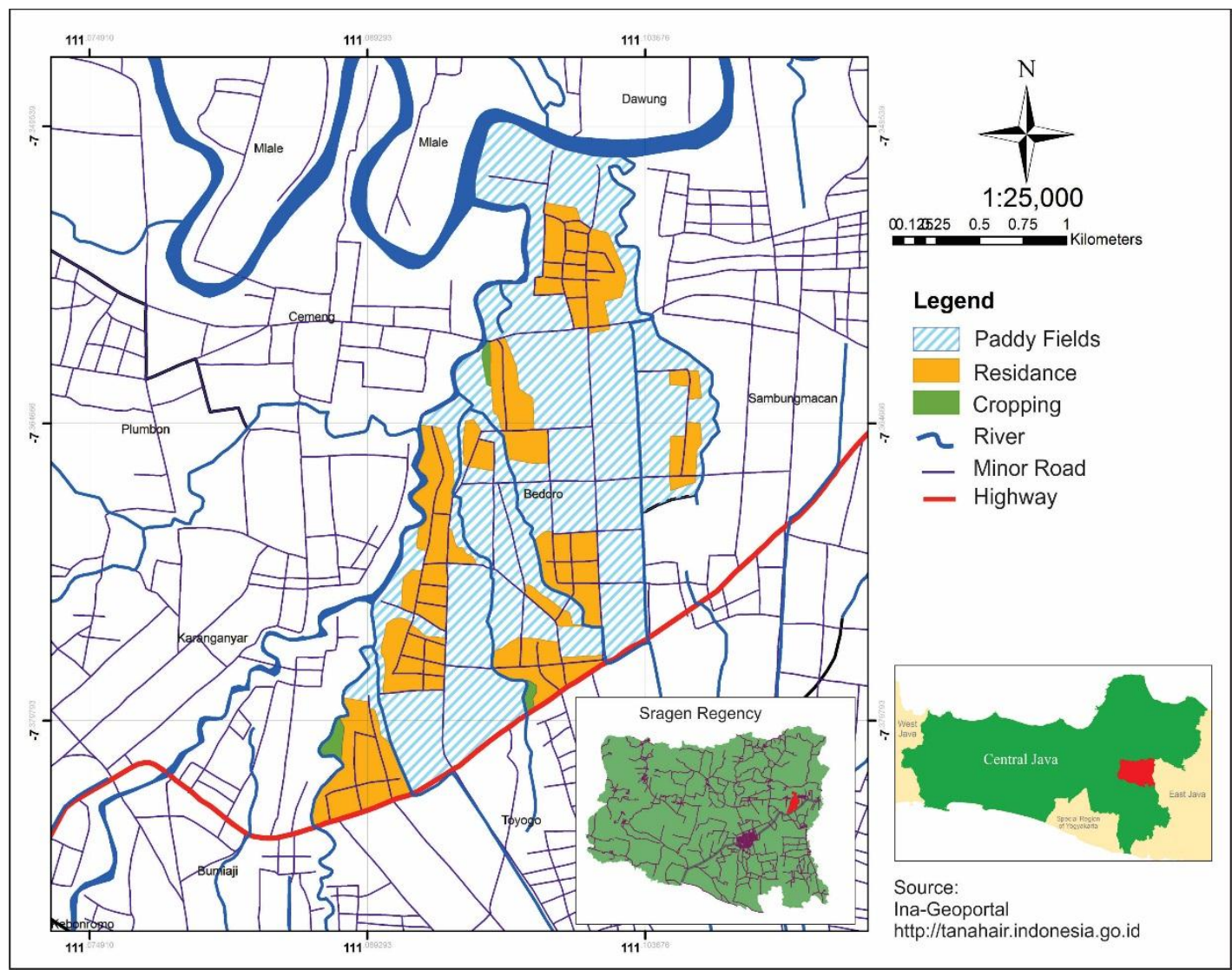

Figure 1. Map of the research location.

The validity test used in this study is content validity. Content validity shows where the contents of a test or measuring device reflect the achievement of things to be measured or tested. The content validity formula used is the Gregory formula. To get the content validity coefficient, two panelists (expert) are required to match the indicators with the items of the instrument by assessing relevant or less relevant. The Gregory formula is as follows:

$$
\text { Content Validity }(\mathrm{CV})=\frac{D}{A+B+C+D}
$$

where:

$\mathrm{A}=$ The number of items that are less relevant according to the two panelists

$\mathrm{B}=$ The number of items that are less relevant according to panelists I and relevant according to panelists II
$\mathrm{C}=$ The number of items that are relevantaccording to panelist I and less relevant according to panelists II

$\mathrm{D}=$ The number of items that are relevant according to the two panelists

The criteria used are if $\mathrm{CV}>0.700$ then the analysis can be continued (Gregory, 2007). The calculation of Content Validity (CV) carried out by two panelists can be seen in Table 1 .

Table 1 . The calculation of content validity (CV)

\begin{tabular}{cccc}
\hline Variable & $\begin{array}{c}\text { Number of } \\
\text { items }\end{array}$ & $\begin{array}{c}\text { Content } \\
\text { validity }\end{array}$ & Criteria \\
\hline $\begin{array}{l}\text { Questionnaire } \\
\text { of social data }\end{array}$ & 15 & 1 & Valid \\
\hline
\end{tabular}

To find out the reliability of instruments, in this research used alpha formula (formula used to 
find the reliability of the instrument whose score is not 1 and 0 (zero), namely as follows:

$$
r_{11}=\alpha=\left[\frac{n}{n-1}\right]\left[1-\frac{\sum S_{i}^{2}}{S_{t}^{2}}\right]
$$

where:

$\mathrm{r}_{11} \quad=$ reliability coefficient of instrument

$\mathrm{N}=$ the number of questions

$\sum S_{i}^{2} \quad=$ the number of squares $\mathrm{S}$ of each item

$S_{t}^{2} \quad=$ the square of the overall item

$$
S_{t}=\frac{1}{N} \sqrt{N \sum X^{2}-\left(\sum X\right)^{2}}
$$

Reliability criteria are as follows:

$0.91-1.00=$ very high

$0.71-0.90=$ high

$0.41-0.70=$ enough

$0.21-0.40=$ low

Negative $-0.20=$ very low (Masidjo, 1995)

The number of farmers involved in the reliability test was 30 farmers. The calculation of the reliability of the questionnaire can be seen in Table 2.

\section{a. Knowledge aspect}

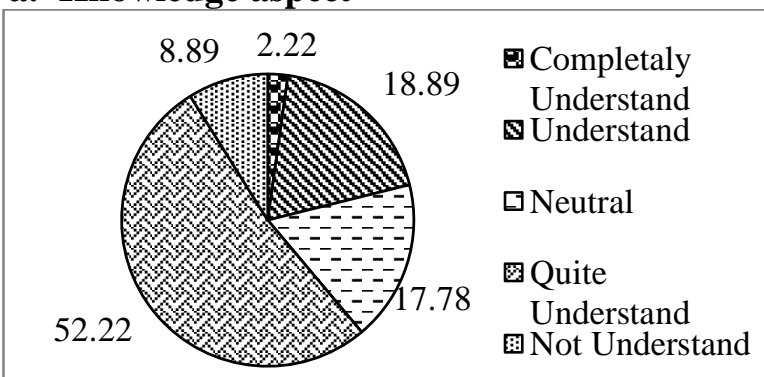

Figure 2. Community knowledge of heavy metal (\%).

Community knowledge about heavy metals in the environment is still low. Based on Figure 2 it is known that $61.11 \%$ (the sum of quite understand and not understand) of the community doesn't understand that the presence of heavy metals in the environment can cause many problems. The presence of heavy metals especially $\mathrm{Cd}$ metal in the agricultural land can cause changes in the color and texture of the soil (Gabarrón et al., 2017). Agricultural land was
Table 2 The calculation of questionnaire reliability

\begin{tabular}{cccc}
\hline Variable & Amount of & Reliability & Criteria \\
\hline $\begin{array}{c}\text { Questionnaire } \\
\text { of social data }\end{array}$ & 15 & 0.947 & $\begin{array}{c}\text { Very } \\
\text { high }\end{array}$ \\
\hline
\end{tabular}

\section{RESULTS AND DISCUSSION}

Most of the communities around the research location are farmers with inorganic farming systems. The organic farming system is still considered to be less profitable for the surrounding community. Farmers in the location assume that to increase agricultural production by doing fertilizer with high doses. Excessive fertilization contributes significantly to the presence of $\mathrm{Cd}$ in the soil (Qiutong and Mingkui, 2017).

The topographical condition of the research location has a flat land condition with flat land conditions irrigation is not a major problem at the study site. Local farmers at the study site can carry out rice farming throughout the year. Continuous rice cultivation throughout the year can cause various changes in soil properties both morphological, chemical, physical, microbiological and other traits (Roberts, 2014; Sharma et al., 2014).

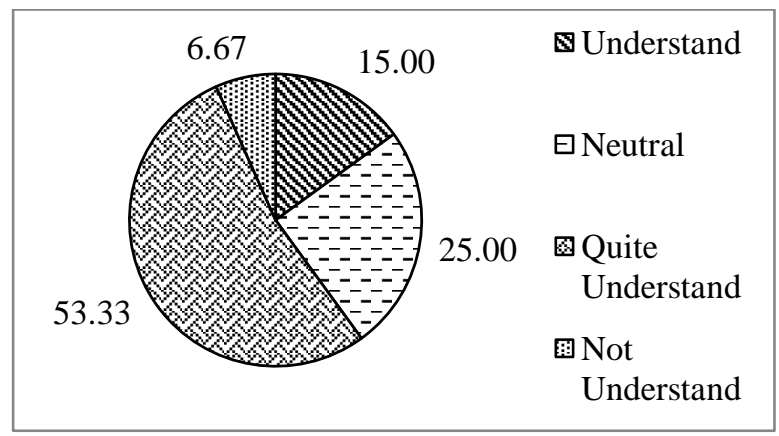

Figure 3. Community knowledge about inorganic fertilizers $(\%)$.

containing Cd metal that exceeding the threshold will turn blackish and the texture will turn harder (hard to hoe). Based on the laboratory test, the $\mathrm{Cd}$ metal content in agricultural land on Bedoro village was $0.28 \mathrm{ppm}$ that content was exceeded the threshold value according to Government Regulation of Indonesia number 101 the year of 2014 that is $0.15 \mathrm{ppm}$.

The contamination of $\mathrm{Cd}$ metal on agricultural land can also be transferred to planted rice plants 
(Gupta et al., 2014). Cd metal contamination in rice plants will affect rice growth, such as the plants growing dwarfs and yellowing the rice leaves and stems (Chang et al., 2013). Furthermore, if rice is consumed by the human will cause several health problems such as disorders of the kidneys, lungs and cardiovascular disease (Qiutong and Mingku, 2017).

The results of the interview with several communities show that most of the people use inorganic fertilizers in the agricultural process. Inorganic fertilizers commonly used by the community are $\mathrm{N}, \mathrm{P}, \mathrm{K}$ fertilizers. Inorganic fertilizers contain heavy metals such as $\mathrm{Cd}, \mathrm{Cr}$ and $\mathrm{Pb}$ which if it's used for long-term will result in accumulation on agricultural land (Roberts, 2014). Based on laboratory test it is known that $\mathrm{Cd}$ metal is found in P fertilizers. This is because the raw material to make $\mathrm{P}$ fertilizer comes from phosphate rock containing $\mathrm{Cd}$ metal (Roberts, 2014; Bigalke et al., 2017).

Based on Figure 3 about $60 \%$ (the sum of quite understand and not understand) of the community doesn't understand that the inorganic fertilizer commonly uses contained heavy metals. The level of knowledge of farmers is influenced by age, mostly older farmers. The lack of interest of

\section{b. Awareness aspect}

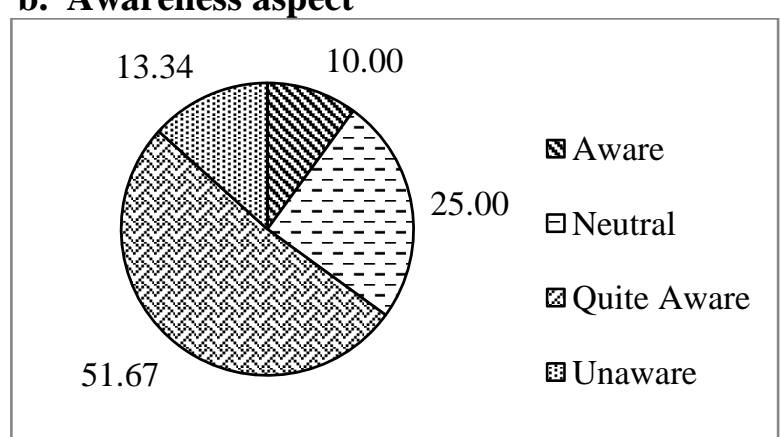

Figure 4. Community awareness about heavy metal pollution due to over-fertilization $(\%)$

Based on Figure 4 it is known that $65.01 \%$ (the sum of quite aware and unaware) of the community unaware of heavy metal pollution due to over-fertilization. Over-fertilization in addition to reducing land productivity can also affect plant growth. This is because the accumulation of $\mathrm{Cd}$ metals will also increase on land and in plant tissue, especially from $\mathrm{P}$ fertilizers. Plants contaminated with $\mathrm{Cd}$ metal will experience several growth disorders such as growing dwarfs young people to become farmers has an impact on the application of technology and knowledge to protect the environment (Susilowati, 2016; Singh and George, 2017). This needs to be watched out because the one character of heavy metal is accumulative, which can cause pollution on agricultural land if used for long term (Tashakor et al., 2014). People also do not know the right dosage of fertilization. During this time the selection of doses used by the community paid more attention to increasing productivity (quantity of crop). The community doesn't consider the quality of crops and the sustainability of agricultural land.

The use of inorganic fertilizers not only has a positive impact in the form of increased land productivity, but also a negative impact on the growth and sustainability of agricultural land. The use of inorganic fertilizers for long-term can cause heavy metal contamination on agricultural land and rice plants. Agricultural land containing heavy metals, especially $\mathrm{Cd}$ metal will decrease productivity. Agricultural land will eventually become hard (difficult to hoe) and its productivity will decrease. This is due to nutrient inequality due to long-term use of inorganic fertilizers (Sharma et al., 2014; Gabarrón et al., 2017).

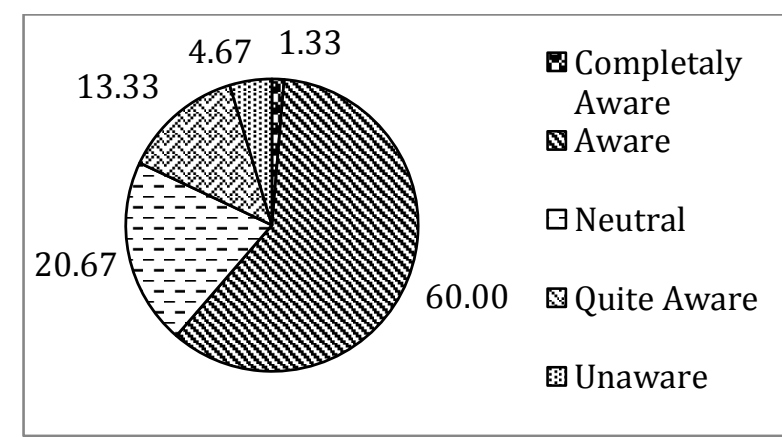

Figure 5. Community awareness to implement environmentally friendly farming systems $(\%)$.

and chlorosis in the stems and leaves (Chang et al., 2013).

Environmentally friendly agriculture is an agricultural system that minimizes outside inputs by considering socio-economic, cultural and natural resource maintenance and environmental sustainability. The aim of environmentally friendly agriculture is to realize agriculture that will produce crops that are safe for consumption. In addition, it is also to create the preservation of 
existing natural resources for the sustainability of land productivity. One way that can be applied to realize environmentally friendly agriculture is to reduce the use of inorganic fertilizers and replace them with organic fertilizer. This method is often known as semi-organic farming (Amelia et al., 2008; Atmojo, 2010). Inorganic fertilizers cannot just be abandoned. This is because the nutrient content in organic fertilizers is very little compared to inorganic fertilizers.

Although people's knowledge and awareness of heavy metals are still low, the community awareness about environmentally friendly agriculture is high. About $61.33 \%$ (the sum of completely aware and aware) (Figure 5) of the community agrees that environmentally friendly agriculture can increase the growth, quality and productivity of agricultural land (Atmojo, 2010; Utari et al., 2018).

\section{c. Behavioral aspects.}

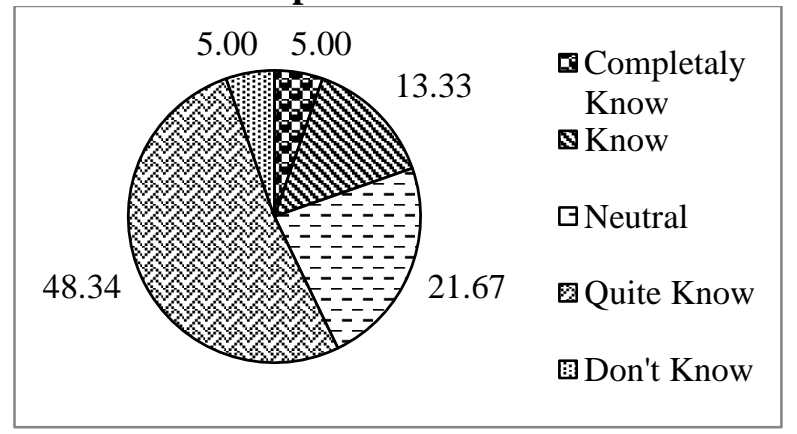

Figure 6. Fertilizing using inorganic fertilizers (\%)

Based on Figure 6 it is known that about $53.34 \%$ (the sum of quite know and don't know) of the community doesn't know that their behavior in using inorganic fertilizers in the long term will increase the accumulation of $\mathrm{Cd}$ metal on agricultural land and rice plant. Inorganic fertilizers, especially $\mathrm{P}$ fertilizers contain $\mathrm{Cd}$ metal derived from the raw ingredient of the producer, namely phosphate rock (Suzuki et al., 1980; Thawornchaisit and Polprasert, 2009; Nunes et al., 2014; Salmanzadeh et al., 2016).

One character of heavy metals is accumulative, in the long term it will accumulate on the ground. As a result, the $\mathrm{Cd}$ metal content in agricultural land will increase and exceed the threshold. Accumulation of $\mathrm{Cd}$ metal in the soil will cause the degradation of agricultural land. In addition, agricultural land contaminated with $\mathrm{Cd}$ metals if planted will result in the crop containing $\mathrm{Cd}$
The community agreed to implement an environmentally friendly agriculture system, in reality, there were still a few people who implemented the system. This is because the availability of organic fertilizers is still limited in the community. Organic fertilizers as known as supporting the implementation of environmentally friendly agriculture systems through balanced fertilization are still difficult to obtain by the community. The need for organic fertilizer to meet plant nutrient needs is also high compared to inorganic fertilizers. This has led to the difficulty of implementing environmentally friendly agriculture systems in the community. The use of organic fertilizers on agricultural land can overcome the problem of nutrient inequality due to the use of inorganic fertilizers in the long term (Atmojo, 2010; Utari et al., 2018). This will affect the increase in plant growth, quality and land productivity.

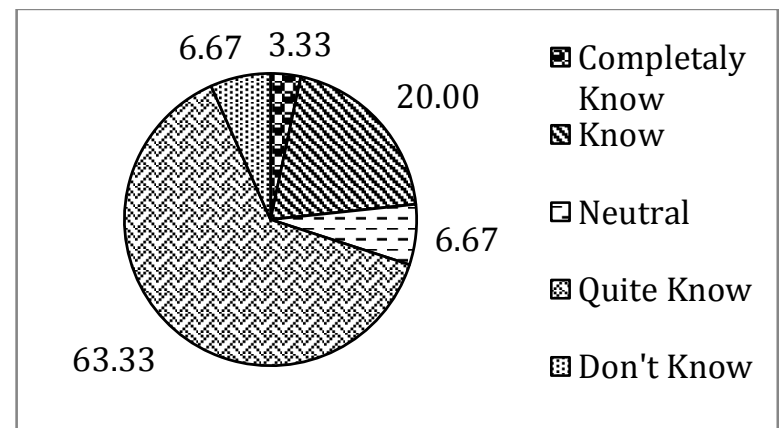

Figure 7. Community planting behavior (\%)

metals as well. This will endanger the people who consume the crop (Agrawal and Sharma, 2006; Han et al., 2010; Alghanmi et al., 2015). Some diseases that can be caused by $\mathrm{Cd}$ metal in humans are disorders of the kidneys, lungs and cardiovascular (Sunarto, 2012). The growth of plants planted on agricultural land contaminated with Cd metal will also be disrupted such as dwarf plants and chlorosis in leaves and stems of plants (Cervantes et al., 2001; Nagarajan and Ganesh, 2015).

Farmers in Bedoro Village, Sambungmacan District, Sragen Regency planted rice three times in one year. Based on the Figure 7 it is known that $70 \%$ (the sum of quite know and don't know) of the community doesn't know that agricultural land that is used continuously for planting (without interspersed with non-paddy crops) will cause land degradation (Amelia et al., 2008; 
Atmojo, 2010). This is due to the accumulation of inorganic fertilizers which can change the physical, chemical and biological soil characteristic (Sharma et al., 2014; Aji et al., 2017; Utari et al., 2018). This cropping behavior is supported by the condition of land that has sufficient irrigation sources to carry out continuous rice planting. This water sufficiency supports high rice productivity. The selling value of rice is higher compared to non-paddy crops so that people grow rice throughout the year.

\section{CONCLUSIONS}

Community knowledge about heavy metals in the environment is still low. The results of the study revealed that about $61.11 \%$ of the community doesn't understand that the presence of heavy metals in the environment could cause many problems. about $60 \%$ of the community doesn't understand that the inorganic fertilizers commonly used contain heavy metals. People who unaware of heavy metal pollution due to over-fertilization were $65.01 \%$. Although people's knowledge and awareness of heavy metals are still low, community awareness about environmentally friendly agriculture is high (61.33\%). About $53.34 \%$ of the community doesn't know that their behavior in using inorganic fertilizers in the long term will increase the accumulation of $\mathrm{Cd}$ metal in agricultural land and rice plant tissue. About $70 \%$ of the community doesn't know that agricultural land that is used continuously to plant (without interspersed with non-rice plants) will cause land degradation.

Knowledge and level of public awareness regarding heavy metal contamination on agricultural land are still low. The effort that can be done is by conducting integrated socialization to the community by involving several related parties such as farmers, the surrounding community, industrialists, academics, health services, agricultural services, environmental agencies and the Central Java provincial research and development center.

\section{REFERENCES}

Agrawal, V., \& Sharma, K. (2006). Phytotoxic effects of $\mathrm{Cu}, \mathrm{Zn}, \mathrm{Cd}$ and $\mathrm{Pb}$ on in vitro regeneration and concomitant protein changes in Holarrhena antidysenterica. Biologia Plantarum, 50(2), 307-310. https://doi.org/10.1007/s10535-006-0027-z

Aji, A., Masykuri, M., \& Rosariastuti, R. (2017). Phytoremediation of Rice Field Contaminated by Chromium with Mendong (Fimbristylis globulosa) to Supporting Sustainable Agriculture. Proceeding International Indonesian Forum for Asian Studies, Borderless Communities \& Nation with Borders Challenges of Globalisation. $\mathrm{P}$ 1236. Retrieved from https://www. researchgate.net/profile/Devanto_Pratomo/p ublication/321831969_Does_Poverty_Affec ts_Child_Labour_and_School_Attendance_ Evidence_from_Indonesia/links/5a33d1f44 5851532e82c898e/Does-Poverty-AffectsChild-Labour-and-School-AttendanceEvidence-from-Indonesia.pdf

Alghanmi, S. I., El-Zayat, T. A., Alhogbi, B. G., Al Sulami, A. F., \& Abdel Salam, M. (2015). Acid leaching of heavy metals from contaminated soil collected from Jeddah, Saudi Arabia: kinetic and thermodynamics studies. International Soil and Water Conservation Research, 3(3), 196-208. https://doi.org/10.1016/j.iswcr.2015.08.002

Amelia, R. A., \& Rachmadiarti, F. (2015). Analisis Kadar Logam Berat $\mathrm{Pb}$ dan Pertumbuhan Tanaman Padi di Area Persawahan Dusun Betas, Desa Kapulungan, Gempol-Pasuruan. Bio Lantern Journal. 4(3), 187-191. Retrieved from http://jurnal mahasiswa.unesa.ac.id/index.php/lenterabio /article/view/13258

Atmojo, S., W. (2010). Manajemen Sumber Daya Lahan Ramah Lingkungan. Surakarta: UNS Press.

Bigalke, M., Ulrich, A., Rehmus, A., \& Keller, A. (2017). Accumulation of cadmium and uranium in arable soils in Switzerland. Environmental Pollution, 221, 85-93. https://doi.org/10.1016/j.envpol.2016.11.03 5

Cervantes, C., Campos-García, J., Devars, S., Gutiérrez-Corona, F., Loza-Tavera, H., Torres-Guzmán, J. C., \& Moreno-Sánchez, R. (2001). Interactions of chromium with microorganisms and plants. FEMS Microbiology Reviews, 25(3), 335-347. 
https://doi.org/10.1016/S0168-6445(01) 00057-2

Chang, Y. Sen, Chang, Y. J., Lin, C. T., Lee, M. C., Wu, C. W., \& Lai, Y. H. (2013). Nitrogen fertilization promotes the phytoremediation of cadmium in Pentas lanceolata. International Biodeterioration and Biodegradation, 85(3), 709-714. https://doi. org/10.1016/j.ibiod.2013.05.021

Chen, W., Chang, A. C., \& Wu, L. (2007). Assessing long-term environmental risks of trace elements in phosphate fertilizers. Ecotoxicology and Environmental Safety, 67(1), 48-58. https://doi.org/10.1016/j.eco env.2006.12.013

Cruz-Paredes, C., López-García, Á., Rubæk, G. H., Hovmand, M. F., Sørensen, P., \& Kjøller, R. (2017). Risk assessment of replacing conventional $\mathrm{P}$ fertilizers with biomass ash: Residual effects on plant yield, nutrition, cadmium accumulation and mycorrhizal status. Science of the Total Environment, 575, 1168-1176. https://doi. org/10.1016/j.scitotenv.2016.09.194

Fauzi, R. P., M, Masykuri \& Sunarto. (2015). Nostoc commune Vaucher ex Bornet \& Flahault Sebagai Fikoremediator Logam Berat Kadmium (Cd (II)). EKOSAINS Journal. 7(2), 84-104. Retrieved from http://pasca.uns.ac.id/s2ilmulingkungan/wpcontent/uploads/sites/25/2016/09/PUBLIK ASI-RACHMAWATI.pdf

Feng, J., Shi, Q., Wang, X., Wei, M., Yang, F., \& Xu, H. (2010). Silicon supplementation ameliorated the inhibition of photosynthesis and nitrate metabolism by cadmium $(\mathrm{Cd})$ toxicity in Cucumis sativus L. Scientia Horticulturae, 123(4), 521-530. https://doi. org/10.1016/j.scienta.2009.10.013

Gabarrón, M., Faz, A., Zornoza, R., \& Acosta, J. A. (2017). Assessment of metals behaviour in industrial soil using sequential extraction, multivariable analysis and a geostatistical approach. Journal of Geochemical Exploration, 172, 174-183. https://doi.org/10.1016/j.gexplo.2016.10.01 5
Gay, L.R. dan Diehl, P.L. (1992). Research Methods for Business and. Management. MacMillan Publishing Company, New York

Gregory, RJ. (2007). Psychological Testing: History, Principles, and Application. New York: Pearson Education.

Gupta, D. K., Chatterjee, S., Datta, S., Veer, V., \& Walther, C. (2014). Role of phosphate fertilizers in heavy metal uptake and detoxification of toxic metals. Chemosphere, 108, 134-144. https://doi.org/10.1016/j. chemosphere.2014.01.030

HE, S., YANG, X., HE, Z., \& BALIGAR, V. C. (2017). Morphological and Physiological Responses of Plants to Cadmium Toxicity: A Review. Pedosphere, 27(3), 421-438. https://doi.org/10.1016/S1002-0160(17) 60339-4

Hindarwati, Y., Retnaningsih Soeprobowati, T., \& Sudarno. (2018). Heavy Metal Content in Terraced Rice Fields at Sruwen Tengaran Semarang - Indonesia. E3S Web of Conferences, 31, 03009. https://doi.org/ 10.1051/e3sconf/20183103009

Ji, W., Chen, Z., Li, D., \& Ni, W. (2012). Identifying the Criteria of Cadmium Pollution in Paddy Soils Based on a Field Survey. Energy Procedia, 16, 27-31. https://doi.org/10.1016/j.egypro.2012.01.00 6

Masidjo. (1995). Penilaian Pencapaian Hasil Belajar Siswa di Sekolah. Yogyakarta: Kanisius.

Nagarajan, M., \& Ganesh, K. S. (2015). Growth and Nutrient Uptake of Paddy (Oryza sativa L.) under Chromium (VI) Treatment, International Journal of Environment and Bioenergy. 10(2), 115-121.

Nunes, L. C., De Carvalho, G. G. A., Santos, D., \& Krug, F. J. (2014). Determination of Cd, $\mathrm{Cr}$ and $\mathrm{Pb}$ in phosphate fertilizers by laserinduced breakdown spectroscopy. Spectrochimica Acta - Part B Atomic Spectroscopy. 97(1), 42-48. https://doi.org/ 10.1016/j.sab.2014.04.011

Nungkat P., Kusuma, Z., H. E. (2015). Effects 
of organic matter application on methane emission from paddy fields adopting organic farming. Journal of Degraded an Mining Lands Management, 2(2), 303-312. https:// doi.org/10.15243/jdmlm.2014.022.303

Qiutong, X., \& Mingkui, Z. (2017). Source identification and exchangeability of heavy metals accumulated in vegetable soils in the coastal plain of eastern Zhejiang province, China. Ecotoxicology and Environmental Safety, 142, 410-416. https://doi.org/ 10.1016/j.ecoenv.2017.03.035

Roberts, T. L. (2014). Cadmium and Phosphorous Fertilizers : The Issues and the Science. Procedia Engineering, 83, 52-59. https://doi.org/10.1016/j.proeng.2014.09.01 2

Salmanzadeh, M., Balks, M. R., Hartland, A., \& Schipper, L. A. (2016). Cadmium accumulation in three contrasting New Zealand soils with the same phosphate fertilizer history. Geoderma Regional, 7(3), 271-278. https://doi.org/10.1016/j.geodrs. 2016.05.001

Salmanzadeh, M., Schipper, L. A., Balks, M. R., Hartland, A., Mudge, P. L., \& Littler, R. (2017). The effect of irrigation on cadmium, uranium, and phosphorus contents in agricultural soils. Agriculture, Ecosystems and Environment, 247, 84-90. https:// doi.org/10.1016/j.agee.2017.06.028

Seshadri, B., Bolan, N. S., Wijesekara, H., Kunhikrishnan, A., Thangarajan, R., Qi, F., Naidu, R. (2016). Phosphorus-cadmium interactions in paddy soils. Geoderma, 270, 43-59. https://doi.org/10.1016/j.geoderma. 2015.11.029

Sharma, U., Paliyal, S. S., Sharma, S. P., \& Sharma, G. D. (2014). Effects of Continuous Use of Chemical Fertilizers and Manure on Soil Fertility and Productivity of MaizeWheat under Rainfed Conditions of the Western Himalayas. Communications in Soil Science and Plant Analysis, 45(20), 26472659. https://doi.org/10.1080/00103624.20 14.941854

Singh, S., \& George, R. (2017). Organic
Farming: Awareness and Beliefs of Farmers in Uttarakhand, India. Journal of Human Ecology, 37(2), 139-149. https://doi.org/10. 1080/09709274.2012.11906458

Sunarto. (2012). Kadmium (Cd) Heavy Metal Pollutant Bioindicator with Microanatomy Structure Gill Analyses of Anodonta Woodiana, Lea. Jurnal Ekosains, 4(1), 2540. Retrieved from http://id.portalgaruda. org/?ref=browse \&mod=viewarticle \&article $=106974$

Supriyadi, S., Rachmawati, S., Herawati, A., \& Purwanto, P. (2019). Soil quality assessment of the rainfed lowland ricefields under organic and conventional farming systems in Kaliwungu (Central Java). Polish Journal of Soil Science, 51(2), 173. https://doi.org/ 10.17951/pjss.2018.51.2.173

Susilowati, S. H. (2016). Fenomena Penuaan Petani dan Berkurangnya Tenaga Kerja Muda Serta Implikasinya Bagi Kebijakan Pembangunan Pertanian Farmers Aging Phenomenon and Reduction in Young Labor: Its Implication for Agricultural Development. Forum Penelitian Agroekonomi, 34, 35-55. https://doi.org/ $0216-4361$

Suzuki, S., Djuangshi, N., Hyodo, K., \& Soemarwoto, O. (1980). Cadmium, copper, and zinc in rice produced in Java. Archives of Environmental Contamination and Toxicology, 9(4), 437-449. https://doi.org/ 10.1007/BF01055296

Tashakor, M., Yaacob, W. Z. W., Mohamad, H., Ghani, A. A., \& Saadati, N. (2014). Assessment of selected sequential extraction and the toxicity characteristic leaching test as indices of metal mobility in serpentinite soils. Chemical Speciation and Bioavailability, 26(3), 139-147. https://doi. org/10.3184/095422914X14036277112433

Thawornchaisit, U., \& Polprasert, C. (2009). Evaluation of phosphate fertilizers for the stabilization of cadmium in highly contaminated soils. Journal of Hazardous Materials, 165(1-3), 1109-1113. https://doi. org/10.1016/j.jhazmat.2008.10.103 
Utari, R. D., Masykuri, M., \& Rosariastuti, M. M. A. R. (2018). Enhancing Chromium Phytostabilization Using Chelator (Agrobacterium sp. I 26, and Manure) to Support Growth and Quality of Rice (Oryza sativa L.), 15(2), 83-92. https://doi.org/10. 15608/stjssa.v15i1.20818
Zhu, D., Ke, X., Wu, L., Huang, Y., Christie, P., \& Luo, Y. (2017). Refinement of Methodology for Cadmium Determination in Soil Micro-Arthropod Tissues. Pedosphere, 27(3), 491-501. https://doi.org/ 10.1016/S1002-0160(17)60345-X 